\title{
Integrating knowledge-based multi-criteria evaluation techniques with GIS for landfill site selection: A case study using AHP
}

\section{Povezavanaznanjuutemeljenomnogokriterijskometodoocenjevanja s sistemom GIS zaizbirolokacije odlagališča odpadkov}

Fagbohun, B.J.* and Aladejana, 0.0.

The Federal University of Technology, Department of Remote Sensing and Geoscience Information System, Akure, Ondo State, P.M.B 704, Nigeria

*jfahb328@gmail.com

\begin{abstract}
A major challenge in most growing urban areas of developing countries, without a pre-existing land use plan is the sustainable and efficient management of solid wastes. Siting a landfill is a complicated task because of several environmental regulations. This challenge gives birth to the need to develop efficient strategies for the selection of proper waste disposal sites in accordance with all existing environmental regulations. This paper presents a knowledge-based multi-criteria decision analysis using GIS for the selection of suitable landfill site in Ado-Ekiti, Nigeria. In order to identify suitable sites for landfill, seven factors - land use/cover, geology, river, soil, slope, lineament and roads - were taken into consideration. Each factor was classified and ranked based on prior knowledge about the area and existing guidelines. Weights for each factor were determined through pair-wise comparison using Saaty's 9 point scale and AHP. The integration of factors according to their weights using weighted index overlay analysis revealed that $39.23 \mathrm{~km}^{2}$ within the area was suitable to site a landfill. The resulting suitable area was classified as high suitability covering $6.47 \mathrm{~km}^{2}$ (16.49\%), moderate suitability $25.48 \mathrm{~km}^{2}(64.95 \%)$ and low suitability $7.28 \mathrm{~km}^{2}(18.56 \%)$ based on their overall weights.
\end{abstract}

Key words: landfill, GIS, AHP, environmental management, spatial planning

\section{Izvleček}

Pomembna naloga $\mathrm{v}$ mnogih hitro rastočih mestnih naselbinah $\mathrm{v}$ deželah $\mathrm{v}$ razvoju, ki nimajo izdelanega plana rabe prostora, je zagotoviti trajnostno in učinkovito ravnanje s trdnimi odpadki. Izbira lokacije ni lahka spričo zapletene okoljske zakonodaje. Odtod izvira potreba po izdelavi učinkovitih scenarijev izbiranja primernih odlagališč v skladu z vso obstoječo okoljsko regulativo. $V$ tem članku poročamo o na znanju utemeljeni mnogokriterijski analizi, opravljeni v povezavi z geografskim informacijskim sistemom (GIS) za izbiro primerne lokacije odlagališča v nigerijskem mestu Ado-Ekiti. Pri izbiri so upoštevali sedem faktorjev - uporabnost, geološko sestavo, rečno mrežo, vrsto tal, nagib zemljišča, razpokanost kamnine in cestno omrežje. Vsak faktor so razdelili na razrede in ga rangirali glede na poprejšnje poznavanje ozemlja in obstoječe smernice. Posameznim faktorjem so pripisovali uteži s po-parnim primerjanjem ob uporabi Saatyjeve 9 stopenjske lestvice in hierarhične analizne metode (AHP). Z integracijo faktorjev glede na njihove uteži ob uporabi utežne indeksne analize podatkovnih slojev so ugotovili, da je $39,23 \mathrm{~km}^{2}$ preiskovane površine primerno za lociranje odlagališča. Na tej površini so opredelili z ozirom na vse faktorje za zelo primerno $6,47 \mathrm{~km}^{2}(16,49 \%)$, zmerno primerno $25,48 \mathrm{~km}^{2}(64,95 \%)$ in malo primerno 7,28 km² (18,56 \%) zemljišča.

Ključne besede: odlagališče odpadkov, geografski informacijski sistem, hierarična analizna metoda, okoljska analiza, prostorsko načrtovanje 


\section{Introduction}

Virtually all activities of man generate a form of solid waste. Source reduction, waste transformation and recycling are widely used methods in the management and reduction of solid waste [1]. However, these methods still leave residual matter behind after recycling and transformation processes. Therefore, an economic approach to get rid of waste termed land filling has been widely adopted [2]. Landfill siting is an extremely difficult and complex task to accomplish, as the site selection process affects different aspects of the environment [3]. Consideration of environmental factors is important as the siting of landfill will affect the surrounding biophysical environment and the ecology of the surrounding area. Social opposition to landfill siting has been one of the greatest obstacles for successfully locating waste disposal facilities. The 'not in my backyard' phenomenon (NIMBY) [4-6] is another challenge in landfill sittings [7], although an approach that uses personal interviews and questionnaires to collect various opinions from opposing parties towards conflict resolution can be applied to resolve the issue [8]. None the less, if a landfill site is properly selected, it is always the most cost efficient method of waste disposal. As a lot of factors must be considered in proper landfill selection, it is critical that a system that is able to analyze several components of the environment with best management practices be utilized [9].

Geographic Information System (GIS) is ideal for this kind of preliminary assessment study due to its ability to manage large volumes of spatial data from a variety of sources, whilst displaying results according to user-defined specification $[1,10]$. MCDM (Multi Criteria Decision Method) is used to compare intangibles and select the best alternative from a set of alternatives. Its main strength lies in breaking down problems into smaller understandable parts, analysing and solving them and then re-integrating them back in a logical manner [11]. The integration of MCDM and GIS provides an efficient platform for consistent ranking of a variety of factors, alongside effective data manipulation and presentations of those factors involved in the selection of a potential landfill. Analytic hierarchy process (AHP) is one of the GIS-based MCDM that combines and transforms spatial data (input) into a resultant decision (output) in a structured and transparent way. The procedure involves the utilization of geographical data, the manipulation of data according to the decision maker's preferences and specified decision rules, referred to as factors and constrains. AHP is appropriate as a consensus building tool in situations involving a committee or group decision-making [12], such as landfill site selection. Its strength lies in its ability to derive weights associated with the attribute of map layers, and also aggregate the priority for all level of the hierarchy structure including the level representing alternatives.

Several established GIS techniques have been applied to solving various problems that require solutions of a multidisciplinary dimension. Such problems include nuclear waste disposal facility location [13], water resource management [14-16], habitat site development [17], land suitability analysis [18-20], and natural hazards [21, 22] amongst others. A number of GIS methodologies, such as Fuzzy and Boolean overlay, have also been used to solve landfill site selection in the past [23-28]. With the advancement of statistical and computing techniques, several multi-criteria decision making methods have been integrated with GIS to solve landfill site selection problems. Sener et al. (2006) [1] combined remote Sensing and GIS with two different methods of MCDM (Simple Additive Weighing and Analytical Hierarchy Process). The result obtained by the combination of RS and GIS with the two MCDM was compared and found to have similar accuracy. Ahmad et al. (2011) [29] used a combination of RS, GIS and Weighted Linear Combination (WLC), which is a multi-criteria evaluation (MCE) method for the selection of waste disposal sites within Mafraq city of Jordan. They stated that the incorporation of MCE with GIS provides better site selection because of its flexibility in selecting the optimum sites. Shahabi et al. (2012) [30] compared the integration Boolean, index overlay and fuzzy logic models with remote sensing and GIS for the selection of suitable locations for the waste material disposal centre. Their result revealed that a larger area was selected by integrating fuzzy 


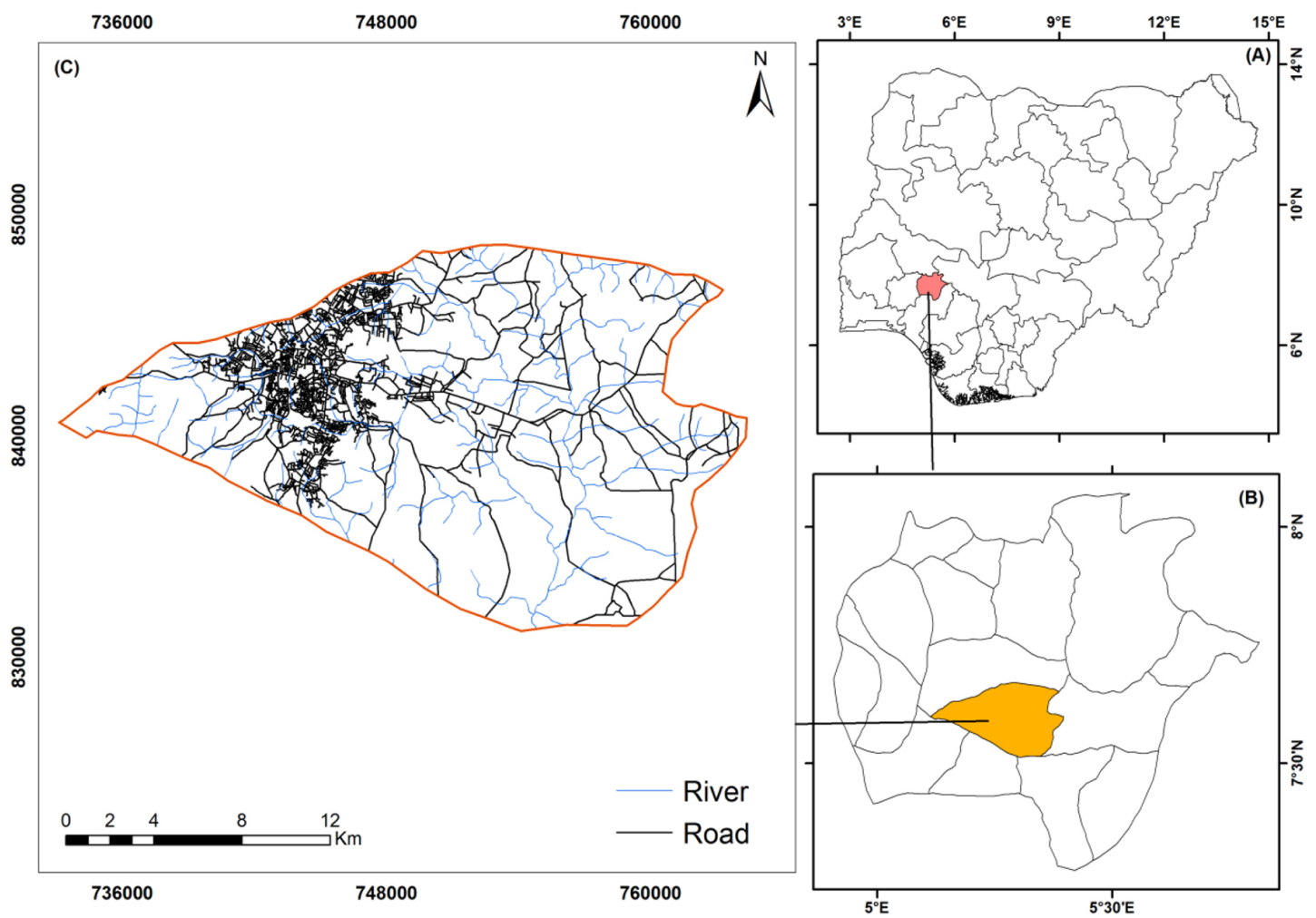

Figure 1: (C) The study area. Inset (A) Nigeria and (B) Ekiti State

logic with RS and GIS as compared to the integrating index overlay with RS and GIS. In Nigeria, the application of remote sensing and GIS for solid waste selection site is limited [10, 3133]. Few studies have attempted to integrate remote sensing, GIS and MCDM in carrying out suitability analysis for landfill selection. The studies by Babalola and Busu (2011) [34] used Multi-criteria Decision Method (MCDM) known as the Analytic Network Process (ANP) in combination with GIS to select landfill sites for solid waste treatment in Damaturu while Olusina and Shyllon (2014) [35] combined MCE with GIS and remote sensing in suitability analysis of optimal landfill location within Lagos, Nigeria. A major drawback in the use of remote sensing and GIS for suitability analysis in Nigeria is the underlying method for integration of various factor data. While the methods adopted by Anifowose et al. (2011) [10], Adeofun et al. (2001) [31], Muhammed et al. (2015) [32] and Oyinloye and Fasakin (2013) [33] has a significant shortcoming as no systematic approach was used in the integration of multiple dataset used in their study, however in the study by Babalola and Busu (2011) [34] and Olusina and Shyllon
(2014) [35], MCDM was not properly implemented. Additionally, most of these methodologies that have been employed using GIS and various MCDM for landfill site selection in Nigeria did not take into consideration the state and interactions of factors locally within an area. As a result of this flaw, spatial prediction ended up biased. This study, therefore, attempts to incorporate pre-existing knowledge about the study area in the integration of MCDM method (AHP) and GIS for the selection of potential landfill sites in Ado-Ekiti, Ekiti State, Nigeria.

\section{The Study area}

Ado-Ekiti is the capital of Ekiti state. It is located in south-western Nigeria (Figure 1). It is a nodal city surrounded by smaller towns such Iworoko in the north, Are and Afao in the east, Iyin and Igede in the west, and Ikere in the south. It has a population of about 450,000. Ado Ekiti falls within the migmatite-gneiss complex of the basement complex sensu stricto $[36,37]$, consisting of migmatite-gneiss, gneisses and granite gneisses, schists, quartzites, granites, charnockitic rocks and unmetamorphosed dolerite dykes [36, 38]. The basement 


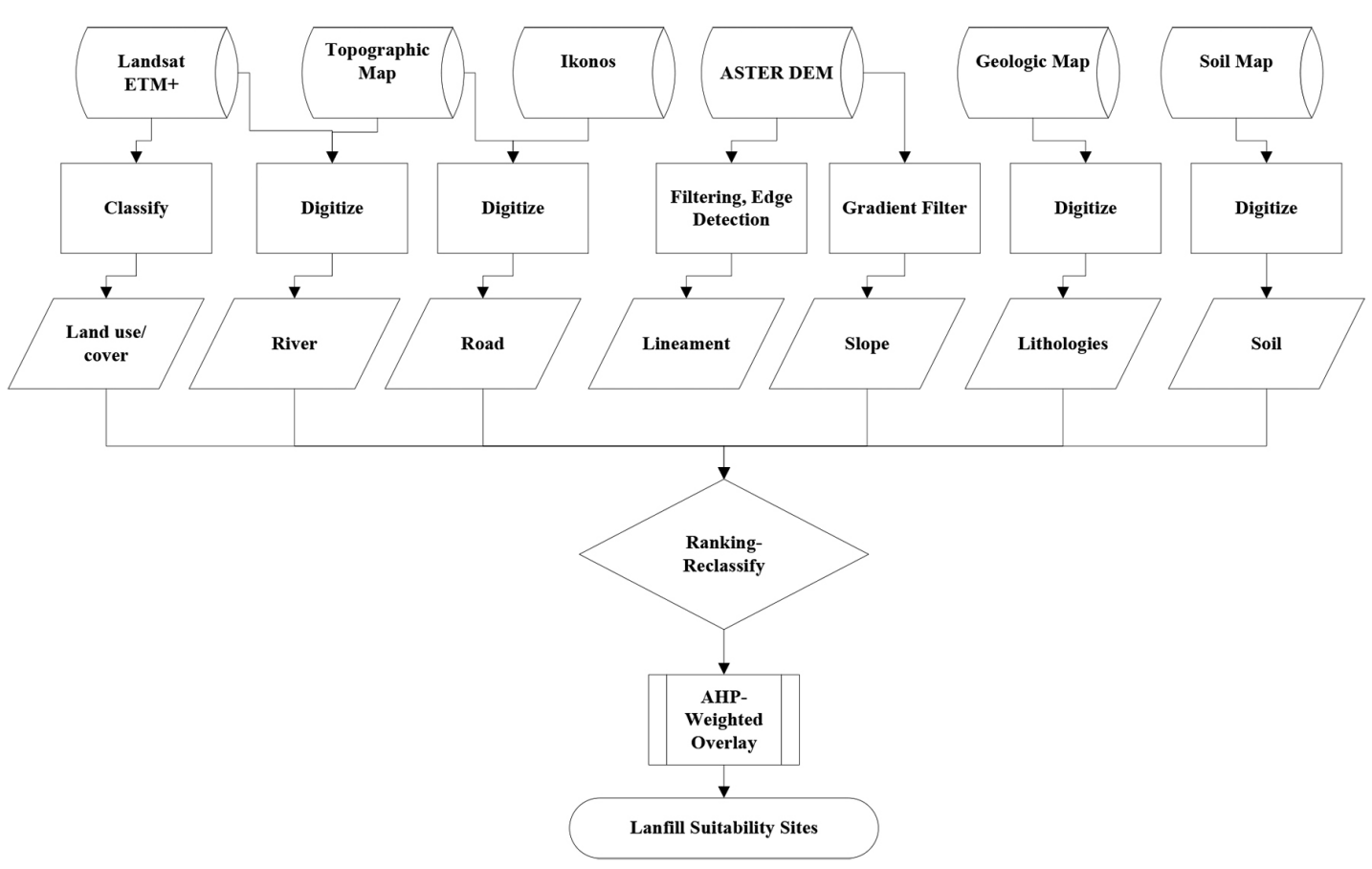

Figure 2: Schematic representation of computational methodology

complex rocks occurring within the study area are the undifferentiated metamorphosed rocks consisting of migmatite-gneiss and gneisses, quartzite and slightly metamorphosed to unmetamorphosed granites and charnockites. The metamorphic rocks of the area are intruded in many places by the granites and charnockites. The granite and the charnockite are emplaced within the metamorphic rocks as stocks in various places. Apart from quartzite, most of these rocks are generally of low porosity as well as negligible permeability. These rocks possess secondary porosities induced by deformation. The area is characterized by dendritic drainage pattern with river Ogbese being the main river with many tributaries. The soil association in the area are the Okemesi, Iwo and Ondo associations formed principally from the rock types in the area [39]. The climatic condition of the study area is sub-tropical. Two major seasons are experienced in the study area. These are the wet and dry seasons. An average annual rainfall of about $1300 \mathrm{~mm}$ is experienced in Ado Ekiti, but it could reach extreme upper and lower values of $1800 \mathrm{~mm}$ and $1100 \mathrm{~mm}$ respectively. The mean monthly temperature is between $23^{\circ} \mathrm{C}$ and $29^{\circ} \mathrm{C}$, with the hottest months being February and March, and the coolest months being August and Sep- tember. The vegetation of the area is characteristic of a typical tropical rain forest with tall trees that form canopies.

The rapid growth of the city, particularly within the last 13 years, has made it one of the fastest growing metropolitan areas in south-western Nigeria. The influx of people into Ado-Ekiti was exacerbated by the changes that took place in the socio-economic and political life of the city. Increase in population also resulted from the establishment of two new higher institutions (Afe Babalola University and Crown Polytechnic) besides those that previously existed (Federal Polytechnic Ado and Ekiti State University).

\section{Materials and methods}

In this study, input data from Landsat of $30 \mathrm{~m}$, IKONOS imagery of $0.5 \mathrm{~m}$, ASTER DEM $30 \mathrm{~m}$ resolution, geological map at a scale of 1:250,000 obtained from Nigeria Geologic Survey, soil map at a scale of 1:500,000 and topographic map at a scale of 1:100,000 were utilized. Remote sensing and GIS analysis involved pre-processing, image transformation, image enhancement, filtering and classification, as summarized in Figure 2. All the data were projected to UTM zone $31 \mathrm{~N}$, WGS 84. 
Table 1: Pair-wise comparison [41]

\begin{tabular}{cc}
$\begin{array}{c}\text { Intensity of } \\
\text { importance }\end{array}$ & Definition \\
\hline 1 & Equal importance \\
\hline 2 & Equal to moderate importance \\
\hline 3 & Moderate importance \\
\hline 4 & Moderate to strong importance \\
\hline 5 & Strong importance \\
\hline 6 & Strong to very strong importance \\
\hline 7 & Very strong importance \\
\hline 8 & Very to extremely strong importance \\
\hline 9 & Extremely strong importance \\
\hline
\end{tabular}

The Landsat image was utilized in providing information about land use/cover of Ado-Ekiti. The IKONOS imagery covering the study area was digitized to obtain the road network in the study area. Slope analysis was then carried out on ASTER DEM covering the area. The ASTEM DEM was also used to derive lineament in the study area. Ground truthing was carried out for the verification of data obtained from remote sensing analysis, and also for hydrogeological and structural investigations. The various criteria were created as layers in GIS environment and structured in a geodatabase to ensure consistency of the data during spatial analysis. All datasets obtained were classified according to the recognised guidelines for landfill selection [40]. The weight for each factor was generated through pair-wise comparison (Table 4). The derived weights were then used to integrate the factors using weighted index overlay analysis (Table 5).

\section{Analytical Hierarchy Model (AHP)}

In AHP developed by Saaty (1980) [41], a complex decision problem is broken down into smaller units, resolved and aggregated back to a larger unit. There are various types of MCDM methods which include Analytical Hierarchy Process (AHP), Inner Product of Vectors (IPV), Multi-Attribute Value Theory (MAVT), Multi-Attribute Utility Theory (MAUT), Multi-Attribute Global Inference of Quality (MAGIQ), Goal Programming, ELECTRE (Outranking), PROMETHÉE (Outranking), Data Envelopment Analysis, The Evidential Reasoning Approach, Dominance-based Rough Set Approach (DRSA), Simple Additive Weighing(SAW), Aggregat- ed Indices Randomization Method (AIRM), Non-Structural Fuzzy Decision Support System (NSFDSS), Grey Relational Analysis (GRA) and the Superiority and Inferiority ranking method (SIR method), however AHP has widespread applicability due to its flexibility and easy implementation [42].

AHP relies on the judgement of experts to derive priority scales. The comparison is based on Table 1. Saaty (1980) [41] suggests that if the consistency ratio exceeds 0.1 , the set of judgments may be too inconsistent to be reliable.

For this study, the pair-wise comparisons for seven layers were conducted based on a comparison between the layers and their importance to appropriately siting a landfill. Based on this, a $7 \times 7$ matrix was formed. Using this matrix, three crucial steps were further performed to calculate the normalized principal eigenvector. In step 1 , the values of $j$ (column) were added up, while in step 2, each element of the column was divided by the corresponding sum of the column to derive the relative weight matrix. In step 3, the normalized principal eigenvector was obtained by averaging across the rows. This provided the factor weights, which were further normalized by multiplication by 100 (Table 4). As a rule of thumb, in checking the consistency of the comparison, the consistency ratio (CR) must always be $\leq 0.1$ for an acceptable comparison. If the ratio is $>0.1$, the matrix should be re-evaluated [43].The consistency ratio is calculated as follows:

$C R=\frac{C I}{R I}$

where $C I$ is consistency index and $R I$ is random consistency index.

$C I=\frac{\lambda_{\max }-n}{n-1}$

where $\lambda_{\max }$ is the principal eigenvalue and $n$ is the number of comparisons.

The random consistency indices used to calculate the consistency ratio is shown in Table 2.

The consistency check for the thematic layers used in the landfill site selection are $\lambda_{\max }=7.29695, C I=0.0494921, \mathrm{n}=7, C R=$ 0.037494 , which is far less than the threshold level of $0.1, R I=1.32$ (from Table 2). This indicates a level of consistency. 
Table 2: Random indices for matrices of various sizes

\begin{tabular}{ccccccccccc}
\hline Matrix size & 1 & 2 & 3 & 4 & 5 & 6 & 7 & 8 & 9 & 10 \\
\hline RI & 0 & 0 & 0.58 & 0.90 & 1.12 & 1.24 & 1.32 & 1.41 & 1.45 & 1.49 \\
\hline
\end{tabular}

Table 3: Sobel filters applied in four principal directions

\begin{tabular}{cccccccccccc} 
& N-S & \multicolumn{3}{c}{ NE-SW } & \multicolumn{3}{c}{ NW-SE } & \multicolumn{3}{c}{ E-W } \\
\hline-1 & 0 & 1 & -2 & -1 & 0 & 0 & 1 & 2 & -1 & -2 & -1 \\
\hline-2 & 0 & 2 & -1 & 0 & 1 & -1 & 0 & 1 & 0 & 0 & 0 \\
\hline-1 & 0 & 1 & 0 & 1 & 2 & -2 & -1 & 0 & 1 & 2 & 1 \\
\hline
\end{tabular}

Table 4: AHP Comparison matrix developed to derive weight for each factor

\begin{tabular}{|c|c|c|c|c|c|c|c|c|}
\hline & 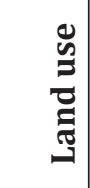 & $\begin{array}{l}\overrightarrow{0} \\
\frac{0}{0} \\
0 \\
\end{array}$ & 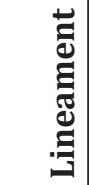 & 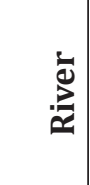 & $\begin{array}{c}\stackrel{0}{a} \\
\frac{a}{\omega}\end{array}$ & $\overline{0}$ & 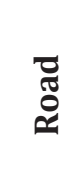 & $\begin{array}{c}\text { Factor } \\
\text { Weight } \\
\text { (\%) }\end{array}$ \\
\hline Land use & 1 & 2 & 3 & 4 & 5 & 7 & 9 & 34 \\
\hline Geology & $1 / 2$ & 1 & 2 & 3 & 4 & 5 & 7 & 23 \\
\hline Lineament & $1 / 3$ & $1 / 2$ & 1 & 2 & 3 & 5 & 6 & 20 \\
\hline River & $1 / 4$ & $1 / 3$ & $1 / 2$ & 1 & 3 & 4 & 5 & 11 \\
\hline Slope & $1 / 5$ & $1 / 4$ & $1 / 3$ & $1 / 2$ & 1 & 3 & 4 & 7 \\
\hline Soil & $1 / 7$ & $1 / 5$ & $1 / 5$ & $1 / 4$ & $1 / 3$ & 1 & 2 & 3 \\
\hline Road & $1 / 9$ & $1 / 7$ & $1 / 6$ & $1 / 5$ & $1 / 4$ & $1 / 2$ & 1 & 2 \\
\hline
\end{tabular}

\section{Land use/cover}

The land use/cover of the study area was obtained from Landsat $\mathrm{ETM}^{+}$imagery obtained in year 2002. Rectified images were subjected to supervised classification with 5 classes using the maximum likelihood algorithm in the ERDAS IMAGINE 9.2 Software. The classes obtained were verified using pattern recognition through ground truthing and fieldwork. Supervised classification was done using a composite image of bands 543 . Arable farm, forest, built-up, rock and water body, which are most significant land covers in the study area, were extracted. Due to the environmental laws and NIMBY problems experienced in Ado-Ekiti, landfill sited on arable farms (parcels of lands used for farming) is the best option. Therefore, arable farm, forest, built-up, rock, and water body were ranked $53,22,16,6$, and 4 , respectively (Figure 3a).

\section{Geology}

The Geologic map covering the study area produced by the Geological Survey of Nigeria (Sheet 61) at the scale 1:250,000 was scanned and imported into ArcGIS 10.2 environment, where it was georeferenced based on the UTM in Geographic Coordinate. The geology of the area was then captured by digitizing. The major lithologic unit in the study area are Migmatite-gneiss, granite and charnockite. Quartzites occur mainly as minor elongate bodies within the migmatite-gneiss and charnockite. The rocks in the study area are ranked based on their aquifer properties and secondary porosity. Quartzite, which is highly fractured indicating high secondary porosity, with good aquifer properties, is ranked lowest (9). The presence of intense fracturing in quartzite makes the groundwater vulnerable to pollution; hence, it is not suitable for landfill. The migmatite-gneiss complex is ranked 18. Al- 

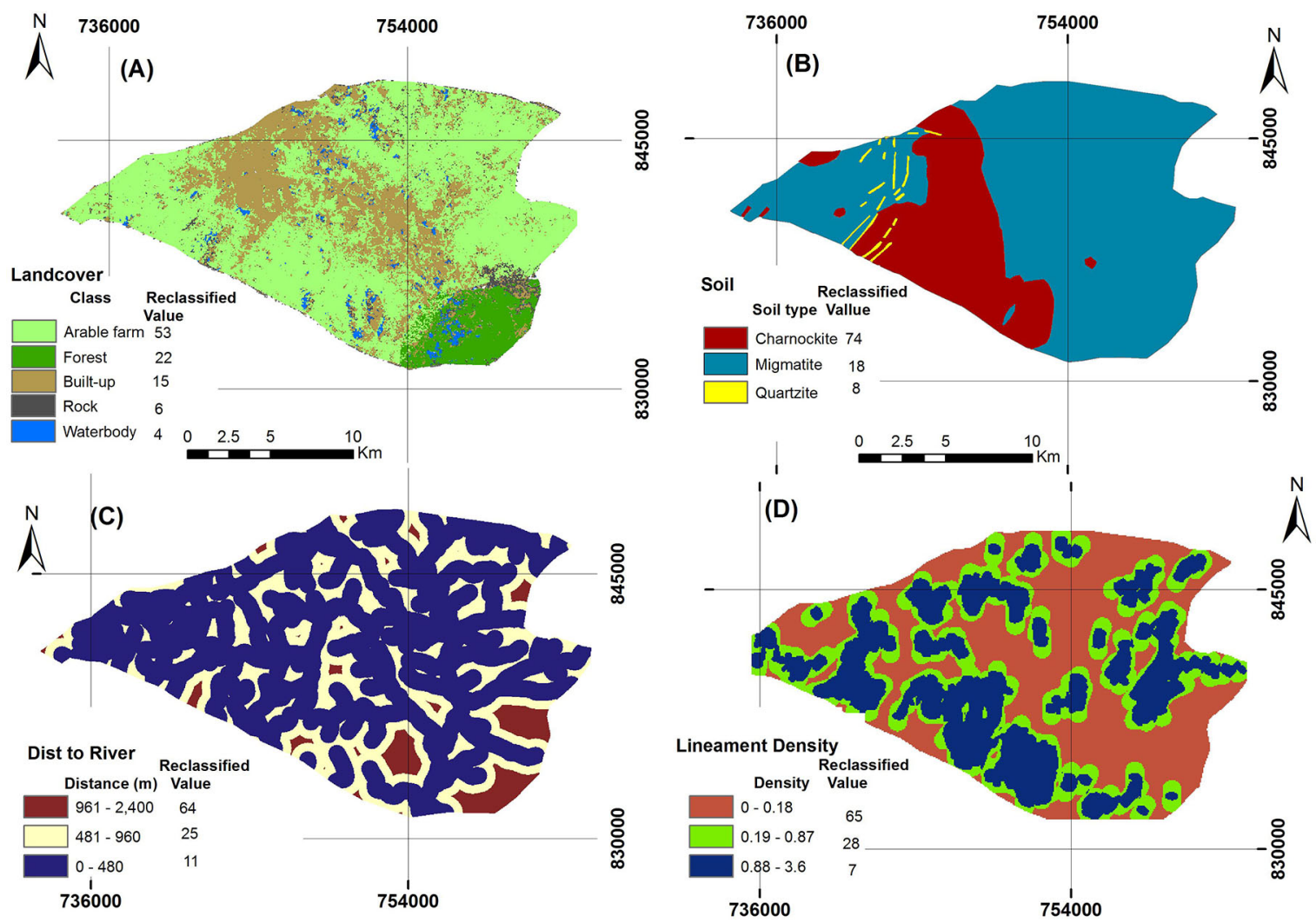

Figure 3: (a) land cover, (b) geology, (c) distance to river, (d) lineament density

though the migmatite-gneiss has also suffered similar deformation as quartzite, however, it is less brittle compared with quartzite resulting in less development of fractures. Deformation within the migmatite-gneiss complex produces more of folding due to the ductile nature of the rock. Charnockitic and older granites are the youngest rock type in the study area. They intrude the migmatite-gneiss complex in various places. They contain less fracture because they have suffered little deformation as compared to the quartzite and migmatite-gneiss complex of the Pre-Cambrian age. The charnockitic and granitic rocks were ranked 73 (Figure 3b). The various rock types are rasterized with the cell size specified as $30 \mathrm{~m}$.

\section{River}

The topographic map sheet 244 covering Ado-Ekiti at the scale of 1:100,000 was scanned and imported into ArcGIS 10.2 environment, where it was georeferenced based on UTM in Geographic Coordinate. The drainage system was digitized. Other streams not present on the topographic map were extracted from Land- sat imagery. The rivers in the study area have a dendritic pattern indicating the presence of a uniform resistance rock. There is a need to site landfill at considerable distance away from river/stream. This is particularly important as leachate getting into the stream can be carried several kilometres downstream causing severe havoc to the ecosystem. Inappropriate landfill sites could threaten the health of hydrologically connected rivers and groundwater. They also pose great threat to aquatic life. As such, a significant distance away from the river must be ensured for landfill siting. Landfill must be sited at considerable distance away from river to prevent leachate, finding its way into the river. Distance to the rivers was computed using Euclidean distance function. This was then reclassified into three suitability distances $(<480 \mathrm{~m}$, 481-960 $\mathrm{m}$ and $>960 \mathrm{~m}$ ).These suitability distances were ranked according to their suitability. Distance greater than $960 \mathrm{~m}$ from river was ranked 76; distance of 480-960 m away from river was ranked 19 , while distance less than $480 \mathrm{~m}$ is ranked 5 (Figure $3 \mathrm{c}$ ). 


\section{Lineament}

Lineaments are the principal controllers of groundwater occurrence in any basement environment. Being weak zones, they usually serve as conduits for movement or accumulation of groundwater in the subsurface. Therefore, it is expedient that no landfill site is situated around zones with high lineament concentration, as this can lead to severe pollution of groundwater sources through the process of leaching. The availability of remotely sensed data has helped in interpretation of morphological and geological structures influencing groundwater recharge over large areas. In particular, the digital elevation of models (DEM) has proved to be a reliable source for lineament extraction for topographical, hydrological or geological purposes [44]. Mapping of lineaments in the study area involved the use of image enhancement methods, where the Sobel filter was applied in the four principal directions on ASETR DEM (Table 3). The resulting edge images were combined into a single image in which the maximum pixel value among the four edge images were retained for each pixel. The lineaments were extracted automatedly using PCI Geomatica. The extracted lineaments were further validated by visual interpretation using the four edge images. Normalized Difference Vegetation Index (NDVI) was also used to delineate those that cannot be detected from the filtered image as a result of dense vegetation cover. Detailed evaluation and field visitation revealed that most of the lineaments discovered from the satellite images occurred along lithologic boundaries, where the charnockites occurring as stocks intrude the migmatite-gneiss. Other lineaments occur along the boundaries of quartzites which occur as elongated bodies within the basement rocks. The extracted lineaments were converted to measurable quantity by computing the lineament density using equation 3 . The lineament density map was generated using line density function $[45,46]$. The lineament density range was from 0 to $3.5 \mathrm{~km}$ per square kilometre. The lineament density was further reclassified with low, medium and high densities ranked as 65,28 , and 7 respectively (Figure 3a). Regions in the study area with high lineament densities tend to favour high groundwater availability [47]. It is therefore expedient that landfills be situated in areas with low lineament densities.

$L d=\sum_{i=1}^{i=n} \frac{L_{i}}{A}\left(k m^{-1}\right)$

where $L d$ is defined as the total lengths $\left(L_{i}\right)$ of all recorded lineaments divided by the area $(A)$ under consideration.

\section{Slope}

Slope is an important determinant of several landscape processes, such as erosion potential, soil water content, runoff, velocity of overland and surface runoff. In the construction of landfill sites, slope is a very important consideration, as its stability forms an important part of material weight in a landfill site. It also influences the amount of rainfall that either infiltrates or runs off. Siting landfill on a very steep terrain pose a threat to surface water and natural environment down slope, as both leachate and debris will be washed down during periods of high precipitation. The sub-mapped ASTER data covering the study was reprojected to UTM, WGS 1984 Zone 31N. The reprojected image is then used in slope generation. The slope amount was obtained in degrees from ASTER DEM using 2nd degree polynomial adjustment algorithm [48]. The cell size was specified to $30 \mathrm{~m}$. The slope amount derived was further reclassified into appropriate classes. Regions with slope between $0^{\circ}-3.77^{\circ}$ were classified as flat, the most suitable for landfill siting. Regions with slope ranging from $3.77-8.15^{\circ}$ were classified as gentle slope, regions with slope ranging from $8.15^{\circ}-15.71^{\circ}$ were classified as having moderate slope, while regions with slope ranging $15.71-38.53^{\circ}$ were classified as steep slope. Based on their suitability for siting landfill, they were ranked 60, 25, 10 and 5 respectively (Figure 4a).

\section{Soil}

The soil map produced by Smyth and Montgomery (1962) [39] serves as information for soil data. The various soil types were digitized. The soil association within the study area are Okemesi, Iwo and Ondo. Soil influences the rate and amount of infiltration of rainfall into the 

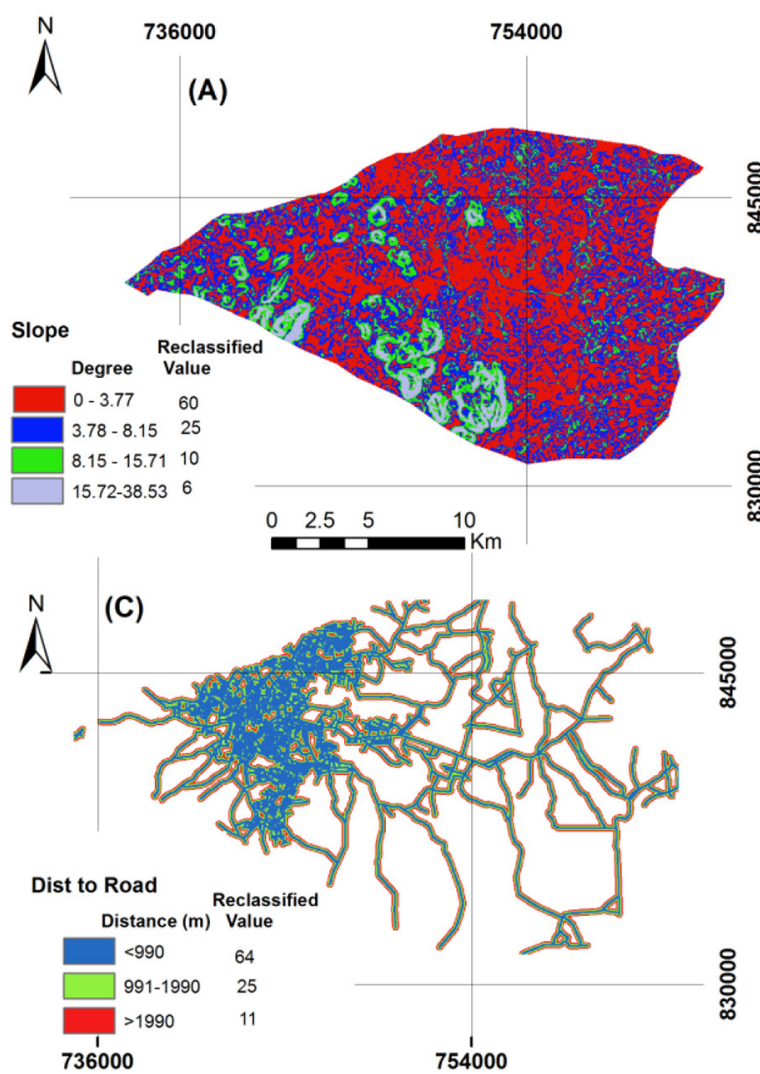

Figure 4: (a) slope, (b) soil, (c) distance to road

subsurface. This property of soil is referred to as permeability. Okemesi association has very coarse texture, gravely, pale greyish brown to brown, usually sandy soils, often very shallow over quartz rubble; Iwo association is coarse textured, greyish brown and brown, sandy to fairly clayey soils overlying weathered rock materials, fresh rock at depths of 7-9 feet, shallow on steep slope; Ondo association is medium to fine textured, orange brown to brownish red, fairly clayey soils overlying orange, brown and mottled clay, fresh rocks at depths of 10-14 ft with occasional rock outcrops [39]. Landfills are better sited on fine grained clayey soil with low permeability, which has the ability to absorb and also retain infiltrating water containing leachate. Based on this fact, the soil in the study area was reclassified with Ondo and ranked as 74, Iwo 18, and Okemesi 8 (Figure $4 \mathrm{~b}$ ). The reclassified soil map was thus converted to raster with $30 \mathrm{~m}$ resolution.

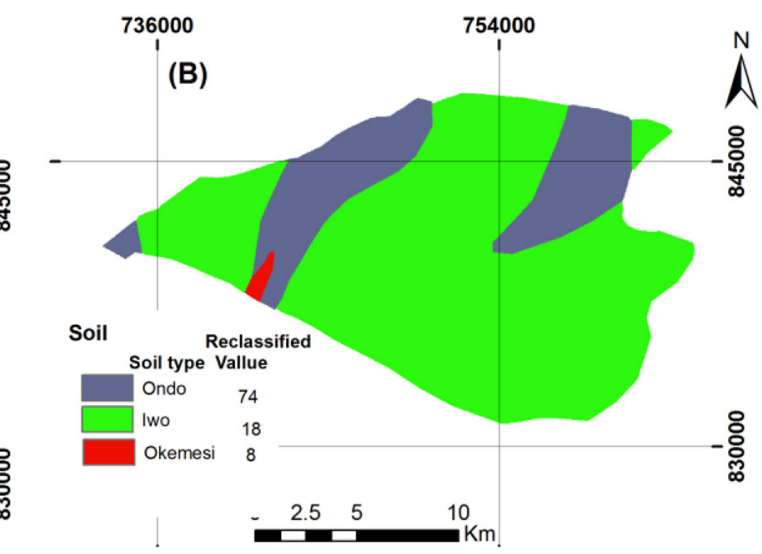

\section{Roads}

The road network within the study area was digitized from IKONOS image while roads linking Ado-Ekiti with other neighbouring towns was digitized from topographic map. Buffer was generated for the roads using the three suitability distances. The three buffers generated were $990 \mathrm{~m}, 1990 \mathrm{~m}$ and $2200 \mathrm{~m}$ respectively. Landfill should be sited not too far from major road to allow easy access. The various suitability distances generated using buffer were converted to raster with cell size of $30 \mathrm{~m}$. The rasterized suitability distances were then reclassified. Distance less than $990 \mathrm{~m}$ away from major road was ranked 64, distance between 991-1990 m was ranked 25, while distance above 1990 was ranked 11 (Figure 4c).

\section{Weighted index overlay}

The weighted index overlay analysis is a straightforward method for combined analysis of multiclass maps to achieve a particular objective. The major advantage of this technique is that knowledge and experience based human 
Table 5: Summary of input layers used in the analysis

\begin{tabular}{|c|c|c|c|c|}
\hline Factor & Data source & Classes & Class rank & Factor weight \\
\hline \multirow{5}{*}{$\begin{array}{c}\text { Land } \\
\text { use/cover }\end{array}$} & \multirow{5}{*}{ Landsat/IKONOS } & Arable land & 53 & \multirow{5}{*}{34} \\
\hline & & Forest reserve & 22 & \\
\hline & & Built-up & 15 & \\
\hline & & Rock & 6 & \\
\hline & & Water body & 4 & \\
\hline \multirow{3}{*}{ Geology } & \multirow{3}{*}{$\begin{array}{c}\text { Geological Survey } \\
\text { of Nigeria, Sheet } 61 \\
1: 250000\end{array}$} & Charnockite & 73 & \multirow{3}{*}{23} \\
\hline & & Migmatite & 18 & \\
\hline & & Quartzite & 9 & \\
\hline \multirow{3}{*}{ Soil } & \multirow{3}{*}{$\begin{array}{c}\text { Soils derived from } \\
\text { crystalline rocks, western } \\
\text { Nigeria 1:50000 }\end{array}$} & Ondo & 74 & \multirow{3}{*}{20} \\
\hline & & Iwo & 18 & \\
\hline & & Okemesi & 8 & \\
\hline \multirow{4}{*}{ Slope } & \multirow{4}{*}{ ASTER DEM } & $0-3.77$ (Flat) & 60 & \multirow{4}{*}{11} \\
\hline & & $3.77-8.15$ (Gentle) & 25 & \\
\hline & & 8.15 - 15.71 (Moderate) & 10 & \\
\hline & & $15.71-38.53$ (Steep) & 5 & \\
\hline \multirow{3}{*}{ Road } & \multirow{3}{*}{ IKONOS } & $<990 \mathrm{~m}$ & 64 & \multirow{3}{*}{7} \\
\hline & & 991-1990m & 25 & \\
\hline & & $>1990 \mathrm{~m}$ & 11 & \\
\hline \multirow{3}{*}{$\begin{array}{c}\text { Lineament } \\
\text { density }\end{array}$} & \multirow{3}{*}{ ASTER DEM and Landsat } & $0-0.18$ (Low) & 65 & \multirow{3}{*}{3} \\
\hline & & $0.19-0.87$ (Medium) & 28 & \\
\hline & & $0.88-3.5$ (High) & 7 & \\
\hline \multirow{3}{*}{ River } & The topographic map & $>1100 \mathrm{~m}$ & 76 & \multirow{3}{*}{2} \\
\hline & sheet 244 of Ado Ekiti & $481-960 \mathrm{~m}$ & 19 & \\
\hline & $1: 100000$ & $<480 \mathrm{~m}$ & 5 & \\
\hline
\end{tabular}

judgment can be incorporated into the analysis. The weights assigned here signify the relative importance of a factor vis-à-vis the overall objective. Most importantly, it considers the relative importance of the factors and the attributes of each factor. As there is no standardized scale for this method, the criteria for assigning weights as in this study is based on knowledge about local conditions, as worked out from the AHP analysis. The 7 prepared thematic maps were overlaid to identify the most suitable site for landfill using weighted index overlay (equation 4) as summarized in Table 5.

$s=\frac{\sum w_{i} s_{i j}}{\sum w_{i}}$

where $w_{i}$ is the weight of ith factor map, $s_{i j}$ is the spatial class weight of $j$ th factor map, $s$ is the spatial unit value of the output map.

\section{Results and discussion}

In this study, a total of seven variables derived from satellite imageries, topographic, geologic and soil maps were considered for the siting of landfill in Ado-Ekiti. The pixel size of all produced map was set at $30 \mathrm{~m}$ resolution. It should be noted that in this selection, financial and political factors were not considered. The process of obtaining the most suitable landfill sites was done using AHP. Here, a pair-wise comparison has the added advantage of determining the consistency ratio, which can be used to ensure the consistency of weights [1]. The combination of all factors based on their weights was achieved using the weighted index overlay function in a GIS environment. From the result obtained (Figure 5), the candidate sites with the highest scores were selected for field verification and for further geotechnical and hydrogeological investigations.

The total suitable area selected by weighted index overlay analysis is $39.23 \mathrm{~km}^{2}$. The selected areas were classified into 3 suitability lev- 


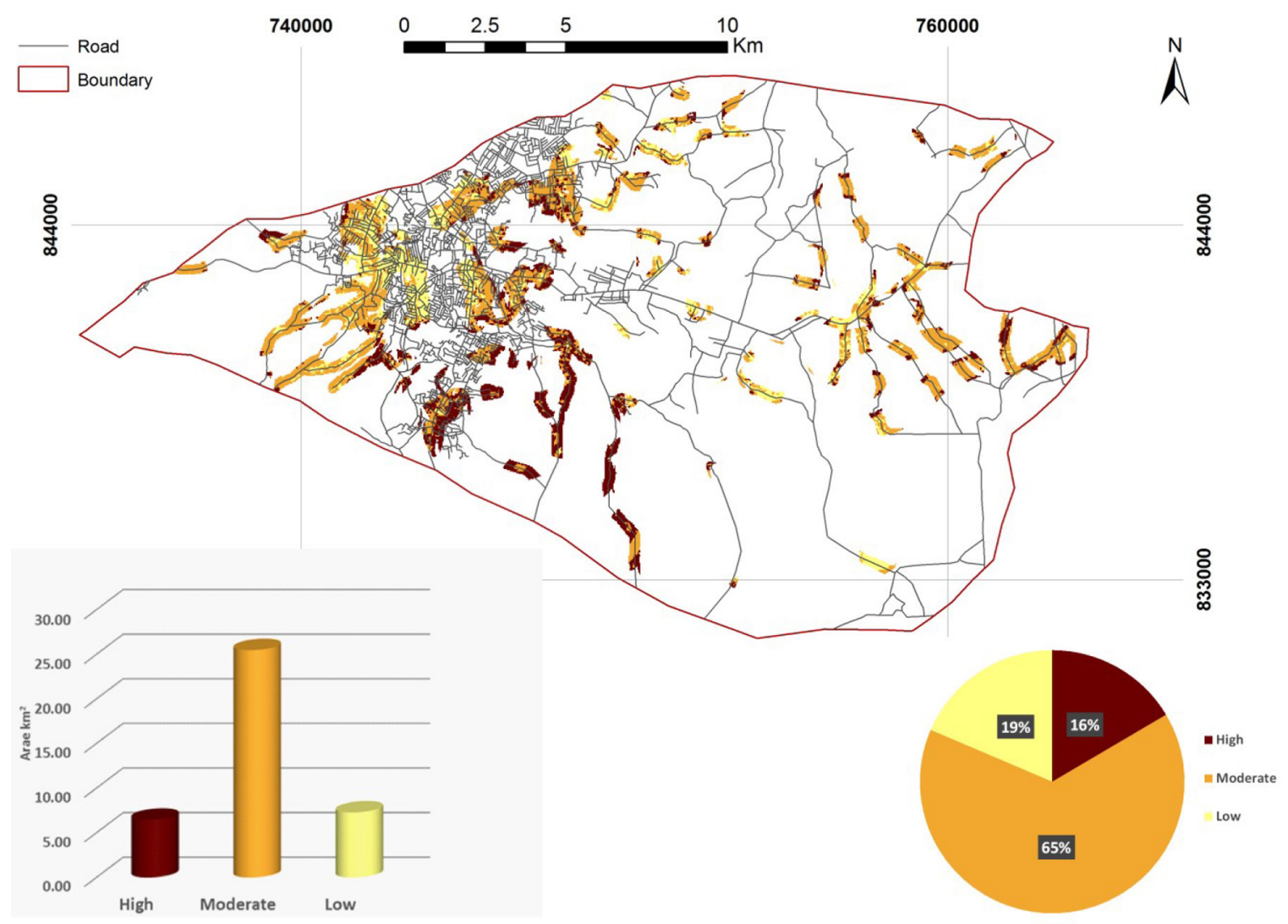

Figure 5: Suitable landfill sites in the study area.

els using an equal interval approach (Table 5). The high suitability class with weight ranging from $46-61$ covers an area of $6.47 \mathrm{~km}^{2}$, which is $16.49 \%$ of the total suitable area, the moderate suitability class with weight ranging from 2745 covers an area of $25.48 \mathrm{~km}^{2}(64.95 \%)$ while the low suitability class with weight ranging from 9-27 covers an area of $7.28 \mathrm{~km}^{2}(18.56 \%)$. In total, $81.44 \%\left(31.95 \mathrm{~km}^{2}\right)$ of the selected area have moderate to high suitability.

Most of the moderately suitable areas fall within the built-up environment and should probably not be considered for landfill due to proximity to residential area, while other moderately suitable areas east of the study area are at a considerable distance from the city centre. A number of highly suitable sites are clustered in the south-western part of the study area. The first proposed site has a total area of $0.32 \mathrm{~km}^{2}$, and it's about $5 \mathrm{~km}$ from the city centre. Although it lies within the region of moderate to high lineament density, it is underlain by charnockitic rocks which are known to be poorest in permeability amongst the rocks in the study area. The high lineament density observed in the area is associated with geologic contact between the migmatite-gneiss and the charnockite. It has been suggested that the influence of lithologic boundary induced lineaments on groundwater flow and recharge is difficult to ascertain [44]. The site falls within the arable land, on a relatively flat to moderate terrain, making it geologically and morphologically suitable, however detailed field survey is required to determine water table height in this area. In Ado Ekiti, arable land cover types are used for subsistent agriculture, and the expropriation of such land can be done by the government with adequate compensation given to the land owner. The second proposed site has a total area of $0.30 \mathrm{~km}^{2}$, about $8 \mathrm{~km}$ from the city centre. Its area spans across a major road that leads to other cities surrounding Ado-Ekiti. Quarrying of sand is carried out along this road. The pits left by quarrying activities can be reclaimed through landfill, however this is subject to further geophysical and geotechnical investigation in order to investigate the depth of groundwater. 
Table 6: Classification of suitability area

\begin{tabular}{cccc} 
Overall weight & Suitability level & Area $\left(\mathbf{k m}^{\mathbf{2}}\right)$ & Percentage $\mathbf{( \% )}$ \\
\hline $46-61$ & High & 6.47 & 16.49 \\
\hline $27-45$ & Moderate & 25.48 & 64.95 \\
\hline $9-26$ & Low & 7.28 & 18.56 \\
\hline
\end{tabular}

\section{Conclusion}

In this study, AHP was combined with existing local and scientific knowledge about the environmental conditions of an area to obtain suitable landfill sites. Although the adopted approach is straightforward as it was easy to make the best decisions as a result of the decision makers' local knowledge about the area, however the method offers a qualitative approach that can be used in the developing countries to identify candidate landfill sites which can be subsequently subjected to further geotechnical and geophysical investigation. Preliminary field studies reveal that some of the lineaments extracted from satellite image are induced by lithologic boundaries which probably have no direct influence on groundwater in the area. Hence, a detailed field study is also required to categorize lineament based on their role on groundwater recharge. The categorized lineaments can be integrated in subsequent GIS-based analysis for landfill site selection. It should also be noted that GIS is not an alternative to field investigation and the result obtained from such analysis cannot be considered ultimate. However, the method offers a time-saving approach to identify potential sites, thereby limiting areas to be considered for further investigation.

\section{References}

[1] Sener, B., Suzen, M.L., Doyuran, V.(2006): Landfill site selection by using geographic information systems. Environ Geol 49, 376-388. DOI: 10.1007/s00254005-0075-2.

[2] Tchobanoglous, G., Kreith, F. (2002): Handbook of solid waste management. McGraw Hill, New York.

[3] Kouznetsova, M., Hauang, X., Ma, J., Lessner, L., Carpenter, D. (2007): Increased rate of hospitalization for diabetes and residential proximity of hazardous waste sites. Environmental Health Perspectives 115, 75.
[4] Kao, J.J., Lin, H. (1996): Multifactor spatial analysis for landfill siting. J Environ Eng, 122(10), pp. 902-908.

[5] Lober, D.J. (1995): Resolving the siting impasse: modeling social and environmental locational criteria with a geographic information system. J Am PlannAssoc, 61(4), pp. 482-495.

[6] Erkut, E., Moran, S.R. (1991): Locating obnoxious facilities in the public sector: an application of the hierarchy process to municipal landfill siting decisions. SocioeconPlannSci, 25(2), pp. 89-102.

[7] Chiueh, P.T., Lo, S.L., Chang, C.L. (2008): A GIS-based system for allocating municipal solid waste incinerator compensatory fund. Waste Management, 28, pp. 2690-2701.

[8] Ishizaka, K., Tanaka, M. (2003): Resolving public conflict in site selection process - risk communication approach. Waste Management, 23, pp. 385-396.

[9] Kontos, T.D., Komilis, D.P., Halvadakis, C.P. (2003): Siting MSW landfills on Lesvos Island with a GIS based methodology. Waste Management \& Research, 21, pp. 262-277.

[10] Anifowose Y.B., Omole K.E., Akingbade O. (2011): Waste Disposal Site Selection using Remote Sensing and GIS: A Study of Akure and its Environs, Southwest-Nigeria. Proceedings of the Environmental Management Conference, Federal University of Agriculture.

[11] Malczewski, J. (1997):. Propagation of errors in multicriteria location analysis: a case study. In: Fandel G, Gal T (eds) Multiple criteria decision making. Springer, Berlin Heidelberg New York, pp. 154-155.

[12] Saaty, T.L. (2008): Decision making with Analytic Hierarchy Process. Int. J. Services Sciences, 1(1), p. 16.

[13] Evans, A.J., Kingston, R., Carver, S. (2004): Democratic input into the nuclear waste disposal problem: the influence of geographical data on decision making examined through a web-based GIS. Journal of Geographical Systems, 6, pp. 117-132.

[14] Jankowski, P., Robischon, S., Tuthill, D., Nyerges, T., Ramsey, K. (2006): Design considerations and evaluations of a collaborative, spatio-temporal decision support system. Transactions in GIS, 10, pp. 335-354.

[15] Makropoulos, C., Butler, D., Maksimovic, C.(2003): A fuzzy logic spatial decision support system for urban 
water management. Journal of Water Resources Planning and Management, 129, pp. 69-77.

[16] Anifowose, A.Y. B., Aladejana, O. O (2015):Evaluation of Groundwater Potential of a Basement Complex Environment Using Geoinformation Technology (A Framework for Water Development in Developing Countries). GEO OBSERVATEUR, NO 22, Journal of Moroccan Centre for Remote Sensing, Rabat, Morocco, pp. 17-28.

[17] Jankowski, P. (2000): Collaborative spatial decision making in environmental restoration management: an experimental approach. Journal of Hydroinformatics, 2, pp. 197-206.

[18] Boroushaki, S., Malczewski, J. (2010): Using the fuzzy majority approach for GIS based multicriteria group decision-making. Computers and Geosciences, 36, pp. 302-312.

[19] Jiang, H., Eastman, R.J. (2000): Application of fuzzy measures in multi-criteria evaluation in GIS. International Journal of Geographical Information Systems, 14, pp. 173-184.

[20] Malczewski, J., (2006): Ordered weighted averaging with fuzzy quantifiers: GIS-based multicriteria evaluation for land-use suitability analysis. International Journal of Applied Earth Observation and Geoinformation, 8, pp. 270-277.

[21] Gorsevski, P.V., Jankowski, P. (2010): An optimized solution of multi-criteria evaluation analysis of landslide susceptibility using fuzzy sets and Kalman filter. Computers and Geosciences, 36, pp. 1005-1020.

[22] Gorsevski, P.V., Jankowski, P., Gessler, P.E. (2006):An heuristic approach for mapping landslide hazard by integrating fuzzy logic with analytic hierarchy process. Control and Cybernetics, 35, pp. 121-146.

[23] Chang, N.B., Parvathinathan, G., Breedenc, J.B. (2008): Combining GIS with fuzzy multicriteria decision-making for landfill siting in a fast-growing urban region. Journal of Environmental Management, 87, pp. 139-153.

[24] Delgado, B.O., Mendoza, M., Lopez-Granados, E., Geneletti, D. (2008): Analysis of land suitability for the siting of inter-municipal landfills in the Cuitzeo Lake Basin, Mexico. Waste Management, 28, pp. 1137-1146.

[25] Geneletti, D. (2010): Combining stakeholder analysis and spatial multicriteria evaluation to select and rank inert landfill sites. Waste Management, 30, pp. 328-337.

[26] Moeinaddini, M., Khorasani, N., Danehkar, A., Darvishsefat, A.A., Zienalyan, M. (2010):Siting MSW landfill using weighted linear combination and analytical hierarchy process (AHP) methodology in GIS environment (case study: Karaj). Waste Management, 30, pp. 912-920.

[27] Nema, K.M., Gupta, S.K. (1999): Optimization of regional hazardous wastemanagement systems: an improved formulation. Waste Management, 19, pp. 441-451.

[28] Zamorano, M., Molero, E., Hurtado, A., Grindlay, A., Ramos, A. (2008): Evaluation of a municipal landfill site in Southern Spain with GIS-aided methodology. Journal of Hazardous Materials, 160, pp. 473-481.

[29] Ahmad, A., Bayen, A., Akihiko, K. (2011):Using GISBased Weighted Linear Combination Analysis and Remote Sensing Techniques to Select Optimum Solid Waste Disposal Sites within Mafraq City, Jordan. Journal of Geographic Information System, 3, pp. 267278.

[30] Shahabi. H., Allahvirdiasl, H., Ali zadeh. M. (2012): Application of GIS Models in Site selection of waste disposal in Urban Area. IOSR Journal of Applied Physics (IOSRJAP), 1(6), p. 0107.

[31] Adeofun C.O., Achi H.A., Ufoegbune G.C., Gbadebo A.M. Oyedepo J.A. (2011): Application of Remote Sensing and Geographic Information System for selecting Dumpsites and Transport Routes in Abeokuta, Nigeria. Proceedings of the Environmental Management Conference, Federal University of Agriculture, Abeokuta, Nigeria.

[32] Muhammed, M., Oyebode, T.S., Bello, A.H., Bako, M.M. (2015): Mapping and Identification of Suitable Dumping Sites for Solid Waste Management in Gwagwalada Area Council of the F.C.T. Nigeria. Journal of Environment and Earth Science, 5(17), pp. 154-161.

[33] Oyinloye, M.A., Fasakin, J.O. (2013): Application of Geographical Information System (GIS) for Siting and Management of Solid Waste Disposal in Akure, Nigeria. IOSR Journal of Environmental Science, Toxicology and Food Technology, 4(2), pp. 06-17.

[34] Babalola. A., Busu. I. (2011): Selection of Landfill Sites for Solid Waste Treatment in Damaturu Town Using GIS Techniques. Journal of Environmental Protection, pp. 2-10.

[35] Olusina J.O., Shyllon, D.0. (2014): Suitability Analysis in Determining Optimal Landfill Location Using Multi-Criteria Evaluation (MCE), GIS \& Remote Sensing. International Journal of Computational Engineering Research, 4(6), pp. 7-20.

[36] Rahaman, M.A. (1988): Recent Advances in the study of the basement complex of Nigeria. In: (Ed) Precambrian Geol Nigeria. Geological Survey of Nigeria, pp. 11-43. 
[37] Dada, S.S. (2006): Proterozoic Evolution of Nigeria. In: Oshin. O (Ed) The Basement Complex of Nigeria and its mineral resources (A Tribute to Prof. M.A.O. Rahaman). AkinJinad \& Co. Ibadan, pp. 29-44.

[38] Rahaman, M.A. (1974): Review of the Basement Geology of South Western Nigeria. In: Kogbe CA (Ed) Geology of Nigeria. Elizabethan Publishing, Lagos, pp. 41-58.

[39] Smyth, A.J., Montgomery, R.F. (1962): Soils and Land use in central western Nigeria. The Government Printers Ibadan, Western Nigeria, 265p.

[40] Environmental Protection Agency. (2006):EPA Landfill Manuals, Manual on Site Selection.

[41] Saaty, T.L. (1980): The analytic hierarchy process, McGraw-Hill, New York.

[42] Coyle, G. (2004): The Analytic Hierarchy Process (AHP). In Practical Strategy. Pearson Education Limited.

[43] Sani Y., Noordin A., Ranya F.A. (2010):Multicriteria analysis for flood vulnerable areas in Hadejia-Jama' are river basin, Nigeria; European J. Sci. Res., 42(1), pp. 71-83.

[44] Mallast, U., Gloaguen, R., Geyer, S., Rödiger, T., Siebert, C. (2011): Derivation of groundwater flow-paths based on semi-automatic extraction of lineaments from remote sensing data. Hydrology and Earth System Sciences. Doi: 10.5194/hess-15-2665-2011.

[45] Edet, A.E., Okereke, C.S., Teme, S.C., Esu, E.O. (1998): Application of remote sensing data to groundwater exploration: a case study of the cross-river state, Southeastern Nigeria. Hydrogeol J., 6, pp. 394-404.

[46] Mogaji, K.A., Omosuyi, G.O., Adelusi, A.O., Lim, H.S. (2016): Application of GIS-Based Evidential Belief Function Model to Regional Groundwater Recharge Potential Zones Mapping in Hardrock Geologic Terrain. Environ. Process. 3:93-123. DOI 10.1007/ s40710-016-0126-6.

[47] Mogaji, K.A., Aboyeji, O.S., Omosuyi, G.O. (2011): Mapping of lineaments for groundwater targeting in the basement complex region of Ondo State, Nigeria, using Remote Sensing and Geographic Information System (GIS) Techniques. International Journal of Water Resources and Environmental Engineering, 3(7), pp. 150-160.

[48] Zevenbergen, L.W., Thorne, C.R. (1987): Quantitative analysis of land surface topography. Earth Surface Processes and Landforms, 12, pp. 12-56. 